\title{
Design for sustainable cultural landscapes - A whole-systems framework
}

\author{
${ }^{1}$ May East, ${ }^{2}$ Ki Utara Pinheiro Gibsone, ${ }^{3}$ Bernard Combes \\ 1. Gaia Education and University of Dundee, Scotland \\ 2. University of Sussex, UK \\ 3. UNESCO, France \\ e-mail: may.east $@$,gaiaeducation.org
}

\begin{abstract}
This article explores how Education for Sustainable Development (ESD) could be used as a guidance framework for the capacity development of those engaged in the process of identifying, protecting, conserving, presenting and transmitting cultural landscapes. It draws insights from the Ecovillage Design Education (EDE) curriculum intended to serve the purpose of educating for the transition to a comprehensive sustainable culture; and incorporates learning objectives from the Education for Sustainable Development Goals report by UNESCO. The framework follows the pattern of the EDE curriculum organised in four dimensions of sustainability and the three dimensions of learning - cognitive, socio-emotional and behavioural. Each of these four dimensions, in turn, contains five modules- thus twenty subject areas in total, all of which need to be considered by sustainable cultural landscape educational programmes. The paper concludes that in order to create a whole-systems guidance framework addressing cultural landscape complexities, a wide variety of viewpoints needs to be considered including community, nature rights and traditional ways of knowing and other participatory epistemologies.
\end{abstract}

Keywords - Education for sustainable development, cultural landscape, ecovillage education, regenerative design, SDGs

\section{INTRODUCTION}

This article explores how Education for Sustainable Development (ESD), understood as a process of lifelong learning (Noguchi, Guevara and Yorozu, 2015), could be used as a guidance framework for the capacity development of those engaged in the process of identifying, protecting, conserving, presenting and transmitting cultural landscapes. It draws insights from the Ecovillage Design Education (EDE) curriculum rooted in the experience of a network of eco-communities acting as research and development centres for carbon-constrained lifestyles (Gaia Education, 2012). These eco settlements are designed in such a way that their way of life, including businesses, economy, social activities, physical structures and technologies, do not interfere with nature's inherent ability to sustain life (East, 2008).

The contemporary notion of sustainable development emerged in the 1970s and the first global description was enshrined in the Brundtland definition of 1987 as 'the development which meets the needs of current generations without compromising the ability of future generations to meet their own needs' (WCED, 1987). The concept of ESD grew to be closely intertwined with key international debates and accords defining sustainable development while addressing the need for education to attend to the growing environmental challenges facing the planet (Leicht, Heiss and Byun, 2018). For instance, Chapter 36 of the outcome document of the United Nations Conference on Environment and Development - Agenda 21- argued for the critical role of education, training and public awareness in achieving sustainable development (UNCED, 1992). Ten years later, a proposal for a Decade of Education for Sustainable Development was included in the Johannesburg Plan of Implementation paving the way for the United Nations General Assembly, at its 57th session to adopt a resolution to launch the UN Decade of Education for Sustainable Development 2005- 2014 (UN, 2002 and UNESCO 2005). The launch of the Decade triggered a global movement to reorient education towards addressing the challenges involved in creating a sustainable world. The initial conceptualisation of sustainable development by the Brundtland Commission was generally understood as a compromise addressing competing interests between environment versus development. Its focus on intra and 
intergenerational equity has divided the world of sustainability theorists and practitioners into a controversial anthropocentric and biocentric debate (Imram, Khorshed, and Beaumont, 2014). Anthropocentrism can be broadly defined as a philosophic discipline within environmental ethics adopting a human-centred belief system that sees nature as a means to human ends and well-being (Kopnina et al., 2018). The concept of anthropocentrism has been challenged by biocentristic interpretations stressing the intrinsic value of all living beings (Breuer, Janetschek and Malerba, 2019) and arguing that human development lacks meaning without healthy ecosystems. This debate provides the conceptual background informing the many storylines defining cultural landscape in the past and at present.

The concept of cultural landscape has evolved over time. Its first use dates back to German authors Ritter (1832), Vogel (1851) and Ratzel (1893) who mainly defined Culturlandschaft as 'landscape modified by human activity' (Potthoff, 2013). In the post-war world, the World Heritage Convention breaks the ground by defining cultural landscape as "combined works of nature and humankind and areas including archaeological sites which are of outstanding universal value from an historical, aesthetic, ethnological or anthropological point of view' (UNESCO, 1972, Art. 1). The 90s saw a rise in debates followed by the adoption of various international bodies of cultural landscape as a conservation category (Rössler 1995, Jacques, 1995). More specifically in 1992 a landmark decision by UNESCO's World Heritage Committee adopted operational guidelines concerning the inclusion of three categories of cultural landscapes, these included clearly defined landscapes designed and created intentionally; organically evolved landscapes; and associative cultural landscapes (UNESCO World Heritage Centre, 2008). This coincides with the period that the international community embraced the notion of sustainability guiding the design of socially just, ecologically sustainable, economically productive, politically participatory and culturally vibrant societies.

This article adopts the definition of cultural landscape as stated by a consortium of European universities gathered under the EU funded project Sustainable Management of Cultural Landscapes - SUMCULA, integrating the three categories as defined by the World Heritage Committee:

'Cultural Landscape is a geographic area, encompassing its cultural and natural resources and the built and intangible heritage therein, continuously shaped by historic and present day evolutionary processes including the adverse or beneficial impacts of human activities, social relations and evolving cultures' (SUMCULA, 2018).

Mediating between anthropocentric and biocentric debates, the notion of cultural landscape reinforces the recognition of key interdependencies between local communities and their heritage, and humankind and its natural environment (Rössler, 2007). Based on this discussion, the article proposes a guidance framework of learning outcomes rooted in the educational experience of eco-communities. These communities explore the contradictions inherent in sustainable living (Vare and Scott, 2007) and demonstrate place-based values and practices for human settlements to thrive within planetary boundaries. Their lived experience provides a firm point of departure for the development of a guidance framework for sustainable cultural landscape identification, conservation, management and transmission.

\section{EDUCATION FOR SUSTAINABLE DEVELOPMENT FOR SDGS}

A generally accepted definition of ESD is an education which promotes knowledge, skills, values and attitudes that empower learners to take informed decisions and responsible actions for environmental integrity, economic viability and a just society, while respecting cultural diversity (Leicht, Heiss and Byun, 2018).

For UNESCO, the objective of ESD is to inspire societal transformation by empowering learners in any education setting to transform themselves and the society they live in. It empowers individuals to become 'global citizens' who assume active roles, both locally and globally, to address the intersecting challenges of our time. Ultimately, ESD plays a key role in enabling the transition to regenerative cultures by building and renewing the capacity of people to participate in co-evolving mutuality - with each other, with the regional ecosystems — in planetary solidarity (Wahl, 2016).

International recognition of ESD as the key enabler for sustainable development has grown over time. The process of setting the universal Sustainable Development Goals (SDGs) originated during the UN Conference on Sustainable Development as a global framework to re-direct humanity towards a sustainable pathway (UN, 2015). There followed a three-year process involving UN Member States, 83 national surveys engaging over seven million people, and thousands of actors from the international community, making it the biggest consultation ever in UN history. The goals have thus been heavily negotiated and have a broad legitimacy among all parties (Lunn et al. 2015). They form the basis of an aspirational world transformation through the Agenda 2030 for Sustainable Development (UN, 2015).

The breadth and depth of the SDGs are unprecedented (UNSSC, 2016). Addressing issues related to poverty, hunger, health, education, gender, energy, work, industry, inequality, cities, consumption, climate, ocean life, ecosystems, peace and partnership. Like every form of an international agreement, the 17 SDGs and 169 targets are the result of an uneasy compromise. They nevertheless represent a moment in history, described as a once in a generation opportunity for transformational change in an interconnected world impacted by a convergence of multiple crises (Nilsson and Stevance, 2016; East, 2018).

Within the spectrum of the Global Goals, Education (SDG 4 ) is both a goal in its own right and a means by which other 
aspects of sustainable development can be achieved (Giangrande et al., 2019). SDG 4 aims to 'ensure inclusive and equitable quality education and promote lifelong learning opportunities for all'. Achieving the Global Goals requires a profound transformation in the way we live, think and act, and the role of ESD is arguably at the heart of the 2030 Agenda for Sustainable Development. But we must ask, what sort of education?

Should we favour Paulo Freire's invigorating critique of the 'banking' model of education, which regards students as mere receivers of education, devoid of creative impetus(1970)? Or should we challenge educators to equip learners with the practical skills, analytic abilities, community competences and philosophical depth necessary to reshape the human presence in the world? UNESCO positions ESD as 'stimulating learning which promote core competencies, such as critical and systemic thinking and collaborative decision-making, while taking responsibility for present and future generations' (2020).

The idea that nothing exists in isolation- but only as part of a system- has long been embedded in written text and oral traditions, and common sense (Orr, 2002). This paper adopts John Muir's understanding that 'when we try to pick out anything by itself, we find it hitched to everything else in the universe' (1911). It proposes a whole-systems learning objectives framework which can be adapted to the bio cultural uniqueness of landscapes and associated communities. The guidance framework seeks a fine balance between acquisition of knowledge, and the awakening of social competencies and skills for learners to enhance, regenerate and co-evolve cultural landscapes. Its holistic nature addresses the crucial point that when designing an ESD framework, we must take in consideration the interdependencies between domains while promoting a broad integrated sense of the unity of things (Orr, 1991).

\section{METHODOLOGY}

It has become convention to describe sustainable development in terms of three overarching themes: economic, social and ecological. These are considered to be the fundamental areas of human experience that need to be addressed in any sustainable development scenario. The Ecovillage Design curriculum recognises and adds one other dimension to these fundamental areas of concern named 'worldview' in recognition that there are always underlying, often unspoken, and sometimes hidden patterns to culture that strongly influence and may, in fact, predetermine economic, social, and ecological relationships. Meanwhile UNESCO argues there are four dimensions to sustainable development - society, environment, culture and economy - which are intertwined, not separate (UNESCO, 2015). Parallels can be drawn between the Ecovillage Design's fourth dimension of 'worldview' and UNESCOs inclusion of culture as a component of sustainable development. They speak to an additional element beyond economic, social and ecological concerns that participate in the interplay of sustainable development.

Design for Sustainable Cultural Landscapes- a Guidance Framework follows the pattern of the EDE curriculum organised in a 'mandala', including the four dimensions of sustainability (Gaia Education, 2005) and the three dimensions of learning - the cognitive, socio-emotional and behavioural (Delors, 1996). Each of these four dimensions, in turn, contains five modules- thus twenty subject areas in total, which need to be considered by curriculum developers and educational institutions offering programmes to sustainable cultural landscape designers, managers and administrators.

While the four-fold mandala of over-arching 'dimensions,' representing an archetypal structural model remains constant (Jung, 1972), the suggested topics and learning objectives of the individual 'modules' are not exhaustive and can evolve and change over time. The framework is thus designed to be inherently flexible, to be adapted to meet the unique needs and issues that are locally relevant and appropriate to specific cultural landscapes and circumstances.

The framework has incorporated learning objectives from the Education for Sustainable Development Goals report by UNESCO (2017) categorised in cognitive - learning to know; social emotional- learning to be and to live together; and behavioural - learning to do and to be (1996). It has also incorporated a series of principles and strategies proposed by Lessons from Vernacular Heritage to Sustainable Architecture (Correia, Dipasquale and Mecca, 2014), as ways to integrate those lessons into the design of a more ecologically responsible built environment. Another set of principles which has informed the development of the framework includes Concepts and Criteria of Deep Design as it offers a response to the challenge of co-designing complex systems (Wann, 1996). Wann's criteria argues for learning the lessons from the ecosystems of which we are part of through a revolutionary alliance between biology, chemistry, and physics, as well as sociology and economics, with design as a key catalyst on the pathway to a livable future.

\section{THE SOCIAL DIMENSION}

Building cooperative groups, organisations, and communities is an endeavour whose immense challenges should not be underestimated. Reconnecting with one another across barriers and borders of misunderstanding and miscommunication calls for clear, calm, firm intention. One of the most cited common reasons for the breakdown of projects is conflict. Propagating successful communities, projects and organisations will necessarily entail a conscious process in which we step out of the cycles of pain and violence that have run through human history and take responsibility for initiating new patterns. Healthy, constructive social skills can be taught and learnt. Peaceful, productive relationships can be consciously designed, and 
developed by deliberate intention rather than left to the capricious, random chance of the moment. Those who engage in the Social Design for Sustainability pathway may gain the competencies and skills to become confident changemakers in building communities and embracing diversity while developing and managing sustainable cultural landscape projects.

Table 1. The social dimension

\begin{tabular}{|c|c|c|c|}
\hline Modules & Cognitive Learning Outcomes & $\begin{array}{c}\text { Social-emotional Learning } \\
\text { Outcomes }\end{array}$ & $\begin{array}{c}\text { Behavioural Learning } \\
\text { Outcomes }\end{array}$ \\
\hline \multirow{4}{*}{$\begin{array}{l}\text { Module } 1 \\
\text { Building Community } \\
\text { \& Embracing } \\
\text { Diversity }\end{array}$} & $\begin{array}{l}\text { Learner is able to identify stages in } \\
\text { group formation. }\end{array}$ & $\begin{array}{l}\text { Learner is able to motivate and } \\
\text { empower others to experience group } \\
\text { forming, storming, norming, } \\
\text { performing. }\end{array}$ & $\begin{array}{l}\text { Learner is able to contribute to } \\
\text { the creation of groups and } \\
\text { communities of practice. }\end{array}$ \\
\hline & $\begin{array}{l}\text { Learner describes common elements } \\
\text { for starting a community, including } \\
\text { forging a common vision, and } \\
\text { instilling trust. }\end{array}$ & $\begin{array}{l}\text { Learner defends diversity and } \\
\text { difference and the richness they } \\
\text { bring to community life. }\end{array}$ & $\begin{array}{l}\text { Learner is able to create a } \\
\text { common vision for a } \\
\text { collective project. }\end{array}$ \\
\hline & $\begin{array}{l}\text { Learner defines the concepts of } \\
\text { extreme and relative poverty and is } \\
\text { able to critically reflect on their } \\
\text { underlying cultural and normative } \\
\text { assumptions. }\end{array}$ & $\begin{array}{l}\text { Learner is able to work with others } \\
\text { to empower individuals and } \\
\text { communities to affect change in the } \\
\text { distribution of power and resources } \\
\text { in the community and beyond. }\end{array}$ & $\begin{array}{l}\text { Learner is able to plan, } \\
\text { implement and evaluate } \\
\text { activities that contribute to } \\
\text { poverty eradication. }\end{array}$ \\
\hline & $\begin{array}{l}\text { Learner understands the concept of } \\
\text { gender, gender discrimination and } \\
\text { violence and knows the current and } \\
\text { historical causes of gender inequality. }\end{array}$ & $\begin{array}{l}\text { Learner is able to recognise and } \\
\text { deconstruct traditional gender roles } \\
\text { in a culturally sensitive yet critical } \\
\text { and emancipatory approach. }\end{array}$ & $\begin{array}{l}\text { Learner is able to plan, } \\
\text { implement and evaluate } \\
\text { strategies to empower people } \\
\text { who are discriminated against } \\
\text { because of their gender. }\end{array}$ \\
\hline \multirow{5}{*}{$\begin{array}{l}\text { Module } 2 \\
\text { Intergenerational } \\
\text { Communication } \\
\text { Skills and Inclusive } \\
\text { Decision-Making }\end{array}$} & $\begin{array}{l}\text { Learner is able to describe a range of } \\
\text { communication methods- authoritative, } \\
\text { expert, generative, empathic. }\end{array}$ & $\begin{array}{l}\text { Learner is able to practise } \\
\text { communication which encourages } \\
\text { social cohesion in changing } \\
\text { environments. }\end{array}$ & $\begin{array}{l}\text { Learner communicates in a } \\
\text { more compassionate way. }\end{array}$ \\
\hline & $\begin{array}{l}\text { Learner understands the concept of } \\
\text { intergenerational relations and how it } \\
\text { relates to cultural landscapes. }\end{array}$ & $\begin{array}{l}\text { Learner promotes inter-generational } \\
\text { relations. }\end{array}$ & $\begin{array}{l}\text { Learner facilitates design } \\
\text { processes including young and } \\
\text { elder generations }\end{array}$ \\
\hline & $\begin{array}{l}\text { Learner evaluates a range of decision- } \\
\text { making processes. }\end{array}$ & \multirow{2}{*}{$\begin{array}{l}\text { Learner is able to raise awareness } \\
\text { about participation of local } \\
\text { communities in decision-making } \\
\text { processes. }\end{array}$} & $\begin{array}{l}\text { Learner uses consensus to } \\
\text { make decisions that everybody } \\
\text { can accept. }\end{array}$ \\
\hline & \multirow{2}{*}{$\begin{array}{l}\text { Learner describes the role of gender } \\
\text { sensitive facilitation in participatory } \\
\text { processes and how it differs from } \\
\text { autocratic leadership. }\end{array}$} & & \multirow{2}{*}{$\begin{array}{l}\text { Learner is able to contribute to } \\
\text { facilitating and implementing } \\
\text { partnerships for sustainable } \\
\text { cultural landscapes projects. }\end{array}$} \\
\hline & & $\begin{array}{l}\text { Learner is able to argue for gender } \\
\text { sensitive facilitated participatory } \\
\text { meetings }\end{array}$ & \\
\hline \multirow{4}{*}{$\begin{array}{l}\text { Module } 3 \\
\text { Leadership and } \\
\text { Governance }\end{array}$} & $\begin{array}{l}\text { Learner is able to recognise the } \\
\text { differences between 'power over' and } \\
\text { 'power with'. }\end{array}$ & $\begin{array}{l}\text { Learner indicates awareness around } \\
\text { issues of rank, power and privilege. }\end{array}$ & $\begin{array}{l}\text { Learner demonstrates } \\
\text { inclusive leadership in groups. }\end{array}$ \\
\hline & $\begin{array}{l}\text { Learner knows different dimensions of } \\
\text { conflict- avoidance, competition, } \\
\text { accommodation, compromise and } \\
\text { collaboration. }\end{array}$ & $\begin{array}{l}\text { Learner stands for processes } \\
\text { addressing conflicts positively. }\end{array}$ & $\begin{array}{l}\text { Learner applies methods of } \\
\text { creative conflict solving } \\
\text { between groups with } \\
\text { conflicting interests. }\end{array}$ \\
\hline & $\begin{array}{l}\text { Learner understands the concepts of } \\
\text { justice and fairness in the context of } \\
\text { local legislative and governance } \\
\text { systems. }\end{array}$ & $\begin{array}{l}\text { Learner argues for civic engagement } \\
\text { tools to engage a diverse cross- } \\
\text { section of stakeholders. }\end{array}$ & $\begin{array}{l}\text { Learner is able to work with } \\
\text { groups that are currently } \\
\text { experiencing injustice. }\end{array}$ \\
\hline & $\begin{array}{l}\text { Learner understands the importance of } \\
\text { inclusion and representing those that } \\
\text { cannot speak for their own rights. }\end{array}$ & $\begin{array}{l}\text { Learner is able to publicly demand } \\
\text { and support the development of } \\
\text { policies promoting justice and } \\
\text { inclusive governance }\end{array}$ & $\begin{array}{l}\text { Learner can become an agent } \\
\text { of change in local decision- } \\
\text { making, speaking up against } \\
\text { injustice. }\end{array}$ \\
\hline
\end{tabular}


Table 1. cont

\begin{tabular}{|c|c|c|c|}
\hline Modules & Cognitive Learning Outcomes & $\begin{array}{c}\text { Social-emotional Learning } \\
\text { Outcomes }\end{array}$ & $\begin{array}{c}\text { Behavioural Learning } \\
\text { Outcomes }\end{array}$ \\
\hline \multirow{4}{*}{$\begin{array}{l}\text { Module } 4 \\
\text { Art, Celebration and } \\
\text { Social } \\
\text { Transformation }\end{array}$} & $\begin{array}{l}\text { Learner understands the concept of } \\
\text { art as tool for social transformation. }\end{array}$ & $\begin{array}{l}\text { Learner is able to raise awareness } \\
\text { about the importance of art as a } \\
\text { powerful tool for social } \\
\text { transformation }\end{array}$ & $\begin{array}{l}\text { Learner contributes to the } \\
\text { dialogue between art and the } \\
\text { state of the world. }\end{array}$ \\
\hline & $\begin{array}{l}\text { Learner knows how to map } \\
\text { activities of artistic and intellectual } \\
\text { life, pursued by means of local } \\
\text { museums, music halls, literary work } \\
\text { and movies. }\end{array}$ & $\begin{array}{l}\text { Learner indicates respect for the } \\
\text { community of life across generations; } \\
\text { those that have lived before, those } \\
\text { that live now, and those that will live } \\
\text { later. }\end{array}$ & $\begin{array}{l}\text { Learner engages in cultural } \\
\text { activities within social } \\
\text { movements of sustainability } \\
\text { and climate action. }\end{array}$ \\
\hline & $\begin{array}{l}\text { Learner knows facts and figures of } \\
\text { common cultural heritage transmitted } \\
\text { from generation to generation within } \\
\text { a community. }\end{array}$ & $\begin{array}{l}\text { Learner respects local seasonal } \\
\text { community traditions, dynamics and } \\
\text { perceptions. }\end{array}$ & $\begin{array}{l}\text { Learner practises skills } \\
\text { transmitted from generation } \\
\text { to generation within a } \\
\text { community. }\end{array}$ \\
\hline & $\begin{array}{l}\text { Learner knows about the concept of } \\
\text { community celebration, } \\
\text { representations, rituals. }\end{array}$ & $\begin{array}{l}\text { Learner reinforces local celebration } \\
\text { and symbolical expressions. }\end{array}$ & $\begin{array}{l}\text { Learner is able to facilitate } \\
\text { celebrations involving } \\
\text { different segments of the } \\
\text { community. }\end{array}$ \\
\hline \multirow{4}{*}{$\begin{array}{l}\text { Module } 5 \\
\text { Education, Social } \\
\text { Networks }\end{array}$} & $\begin{array}{l}\text { Learner understands the important } \\
\text { role of education for sustainable } \\
\text { development as key enabler for } \\
\text { improving people's lives. }\end{array}$ & $\begin{array}{l}\text { Learner is able to recognise the } \\
\text { intrinsic value of education and to } \\
\text { identify their own learning needs in } \\
\text { their personal development. }\end{array}$ & $\begin{array}{l}\text { Learner is able to use all } \\
\text { opportunities for their own } \\
\text { education throughout their } \\
\text { life. }\end{array}$ \\
\hline & $\begin{array}{l}\text { Learner understands education as a } \\
\text { public good and fundamental human } \\
\text { right. }\end{array}$ & $\begin{array}{l}\text { Learner is able to engage personally } \\
\text { with the concept of education for } \\
\text { sustainable development. }\end{array}$ & $\begin{array}{l}\text { Learner builds friendly } \\
\text { relationships with neighbours. }\end{array}$ \\
\hline & $\begin{array}{l}\text { Learner knows the importance of } \\
\text { building resilient cross-sectoral } \\
\text { networks for social good. }\end{array}$ & $\begin{array}{l}\text { Learner is able to raise awareness on } \\
\text { the importance of knowledge sharing } \\
\text { within communities of practice. }\end{array}$ & $\begin{array}{l}\text { Learner is able to facilitate the } \\
\text { empowerment of young } \\
\text { people. }\end{array}$ \\
\hline & $\begin{array}{l}\text { Learner knows about the progression } \\
\text { of networks, communities of practice } \\
\text { and zones of influence. }\end{array}$ & $\begin{array}{l}\text { Learner argues for digital inclusion } \\
\text { for older adults. }\end{array}$ & $\begin{array}{l}\text { Learner is able to encourage } \\
\text { digital literacy of elders of the } \\
\text { community. }\end{array}$ \\
\hline
\end{tabular}

\section{THE ECOLOGICAL DIMENSION}

Thriving cultural landscapes rely on regenerative Earth systems across forests, waterways, biodiversity, oceans, the atmosphere and more. The ecological pathway approaches sustainable design from a whole systems perspective, focusing on life supporting natural functions to ensure that they are not only preserved but regenerated whenever possible. Ecological design is a multifaceted field that requires broad consideration in order to support the fundamental redesign of humanity's impact on Earth. Spanning sustainable agriculture, ecological restoration, green architecture and integrated water and energy systems, this dimension is concerned with sustaining the pattern of ecological interdependencies and nurturing the conditions for all living systems to prosper. It focuses on co-creating dynamic solutions which are carefully adapted to the biocultural uniqueness of distinct cultural landscapes while reducing vulnerability and increasing the ability of systems to adapt to extreme events which are growing in number and ferocity.

This subject area examines the historical roots of ecological design thinking by exploring permaculture, regenerative design, ecological economics, industrial ecology and cradle-to-cradle. Those who engage in the ecological design pathway may gain the knowledge, competencies and skills to become confident changemakers in ecological issues related to healthy interdependent cultural landscape projects.

Table 2. The ecological dimension

\begin{tabular}{|c|c|c|c|}
\hline Modules & Cognitive Learning Outcomes & $\begin{array}{c}\text { Social-emotional Learning } \\
\text { Outcomes }\end{array}$ & $\begin{array}{c}\text { Behavioural Learning } \\
\text { Outcomes }\end{array}$ \\
\hline \multirow{2}{*}{$\begin{array}{l}\text { Module } 1 \\
\text { Whole Systems } \\
\text { Approach to } \\
\text { Ecological Design } \\
\text { within Planetary } \\
\text { Boundaries }\end{array}$} & \multirow{2}{*}{$\begin{array}{l}\text { Learner identifies critical planetary boundaries- } \\
\text { climate change, biodiversity loss, the limits of } \\
\text { the nitrogen and phosphorus cycle, land-system } \\
\text { change- and effective ways to limit, ameliorate } \\
\text { and reverse the effects already triggered by } \\
\text { overstepping them. }\end{array}$} & $\begin{array}{l}\text { Learner conducts awareness } \\
\text { raising activities on planetary } \\
\text { boundaries amongst } \\
\text { communities embedded in } \\
\text { cultural landscapes. }\end{array}$ & $\begin{array}{l}\text { Learner is able to evaluate } \\
\text { whether their lifestyle is } \\
\text { climate friendly and - } \\
\text { given it is not - to revise it. }\end{array}$ \\
\hline & & $\begin{array}{l}\text { Learner is able to collaborate } \\
\text { with others and to develop } \\
\text { commonly agreed strategies to } \\
\text { deal with climate change } \\
\text { impacts in cultural landscapes. }\end{array}$ & $\begin{array}{l}\text { Learner harnesses natural } \\
\text { and climatic resources } \\
\text { creating productive cycles } \\
\text { in the system. }\end{array}$ \\
\hline
\end{tabular}




\begin{tabular}{|c|c|c|c|}
\hline Modules & Cognitive Learning Outcomes & $\begin{array}{c}\text { Social-emotional Learning } \\
\text { Outcomes }\end{array}$ & $\begin{array}{c}\text { Behavioural Learning } \\
\text { Outcomes }\end{array}$ \\
\hline \multirow[t]{3}{*}{$\begin{array}{l}\text { Module } 1 \\
\text { Whole Systems } \\
\text { Approach to } \\
\text { Ecological Design } \\
\text { within Planetary } \\
\text { Boundaries }\end{array}$} & $\begin{array}{l}\text { Learner understands the current climate } \\
\text { change as a human-driven phenomenon } \\
\text { owing to increased greenhouse gas emissions. }\end{array}$ & $\begin{array}{l}\text { Learner promotes campaigns } \\
\text { protecting biodiversity, fisheries } \\
\text { and watersheds, long-term } \\
\text { reforestation programmes, } \\
\text { regenerative land use. }\end{array}$ & $\begin{array}{l}\text { Learner can effectively use } \\
\text { their voice in decision- } \\
\text { making processes to help } \\
\text { cultural landscapes } \\
\text { become more permeable to } \\
\text { wildlife through the } \\
\text { establishment of wildlife } \\
\text { corridors, restoration } \\
\text { ecology and more. }\end{array}$ \\
\hline & $\begin{array}{l}\text { Learner discerns between genetic diversity, as } \\
\text { a repository for life's innovation, and } \\
\text { functional diversity, as the diversity of } \\
\text { interacting species that give a given } \\
\text { ecosystem or the biosphere the capacity for } \\
\text { healthy self-regulation. }\end{array}$ & \multirow[t]{2}{*}{$\begin{array}{l}\text { Learner promotes within } \\
\text { conservation strategies reducing } \\
\text { disaster risks and adapting to } \\
\text { climate change, through } \\
\text { associated ecosystem services. }\end{array}$} & \multirow[t]{2}{*}{$\begin{array}{l}\text { Learner can connect with } \\
\text { local groups working } \\
\text { toward disaster } \\
\text { preparedness and } \\
\text { 'building-back-better'. }\end{array}$} \\
\hline & $\begin{array}{l}\text { Learner enhances preparedness for effective } \\
\text { response and 'building-back-better' in post- } \\
\text { disaster recovery strategies within cultural } \\
\text { landscape management systems. }\end{array}$ & & \\
\hline \multirow[t]{4}{*}{$\begin{array}{l}\text { Module } 2 \\
\text { Water Systems }\end{array}$} & $\begin{array}{l}\text { Learner understands whole systems approach } \\
\text { to bioregional watershed management and } \\
\text { restoration of the hydrological cycles. }\end{array}$ & $\begin{array}{l}\text { Learner communicates the } \\
\text { interdependencies between } \\
\text { restoration of hydrological } \\
\text { cycles, healthy ecosystems } \\
\text { functions and thriving } \\
\text { communities. }\end{array}$ & $\begin{array}{l}\text { Learner is able to reduce } \\
\text { their individual water } \\
\text { footprint. }\end{array}$ \\
\hline & $\begin{array}{l}\text { Learner knowns basic principles of ecological } \\
\text { engineering, rainwater harvesting, } \\
\text { constructed wetlands and the fundamental } \\
\text { processes of biological wastewater treatment. }\end{array}$ & $\begin{array}{l}\text { Learner is able to involve in } \\
\text { local community activities in } \\
\text { improving water and sanitation } \\
\text { management. }\end{array}$ & $\begin{array}{l}\text { Learner is able to } \\
\text { contribute to water } \\
\text { resources management at } \\
\text { the local level. }\end{array}$ \\
\hline & $\begin{array}{l}\text { Learner knows about the global inequality of } \\
\text { distribution of access to safe drinking water } \\
\text { and sanitation facilities. }\end{array}$ & $\begin{array}{l}\text { Learner is able to question } \\
\text { socio-economic differences in } \\
\text { the access to safe drinking } \\
\text { water and sanitation facilities. }\end{array}$ & $\begin{array}{l}\text { Learner undertakes a } \\
\text { mapping of water supply } \\
\text { of the bioregion. }\end{array}$ \\
\hline & $\begin{array}{l}\text { Learner examines the water-related } \\
\text { consequences of climate change. }\end{array}$ & $\begin{array}{l}\text { Learner mobilises stakeholders } \\
\text { to discuss impact of climate } \\
\text { change on water security. }\end{array}$ & $\begin{array}{l}\text { Learner is able to plan, } \\
\text { implement and evaluate } \\
\text { activities that contribute to } \\
\text { increasing water quality } \\
\text { and safety. }\end{array}$ \\
\hline \multirow[t]{4}{*}{$\begin{array}{l}\text { Module } 3 \\
\text { Sustainable Food } \\
\text { Systems }\end{array}$} & $\begin{array}{l}\text { Learner understands essential principles } \\
\text { informing agroecological food systems - } \\
\text { organic, biodynamic, agroforestry, } \\
\text { permaculture. }\end{array}$ & $\begin{array}{l}\text { Learner articulates the multiple } \\
\text { benefits of a localised } \\
\text { sustainable food production in } \\
\text { relation to nutrition, society, } \\
\text { educational, environmental, } \\
\text { economy, employment. }\end{array}$ & $\begin{array}{l}\text { Learner eats locally and } \\
\text { seasonally. }\end{array}$ \\
\hline & $\begin{array}{l}\text { Learner reviews effectiveness of cutting 'food } \\
\text { miles' in food distribution from producer to } \\
\text { consumer. }\end{array}$ & $\begin{array}{l}\text { Learner is able to work with } \\
\text { others to to promote localised } \\
\text { food systems and farm-to-table } \\
\text { schemes which reduce } \\
\text { transportation. }\end{array}$ & $\begin{array}{l}\text { Learner is able to } \\
\text { participate in and influence } \\
\text { decision-making related to } \\
\text { public policies concerning } \\
\text { the promotion of } \\
\text { sustainable agriculture. }\end{array}$ \\
\hline & $\begin{array}{l}\text { Learner knows about the interdependencies } \\
\text { between cultural landscapes and bringing } \\
\text { back 'culture' to agri-culture. }\end{array}$ & $\begin{array}{l}\text { Learner is able to encourage } \\
\text { local food production and trades } \\
\text { enriching cultural landscapes. }\end{array}$ & $\begin{array}{l}\text { Learner is able to connect } \\
\text { with and to promote } \\
\text { networks of sustainable } \\
\text { agriculture. }\end{array}$ \\
\hline & $\begin{array}{l}\text { Learners analyse the benefits of community } \\
\text { supported agriculture in the context of } \\
\text { community, food sovereignty and cultural } \\
\text { landscape. }\end{array}$ & $\begin{array}{l}\text { Learners are able to reinforce } \\
\text { community-supported } \\
\text { agriculture. }\end{array}$ & $\begin{array}{l}\text { Learner is able to cut food } \\
\text { miles through community } \\
\text { supported agriculture, } \\
\text { farmers' markets, co-op } \\
\text { buying. }\end{array}$ \\
\hline
\end{tabular}


Table 2. cont.

\begin{tabular}{|c|c|c|c|}
\hline Modules & Cognitive Learning Outcomes & $\begin{array}{c}\text { Social-emotional Learning } \\
\text { Outcomes }\end{array}$ & $\begin{array}{c}\text { Behavioural Learning } \\
\text { Outcomes }\end{array}$ \\
\hline \multirow[t]{4}{*}{$\begin{array}{l}\text { Module } 4 \\
\text { Affordable and Clean } \\
\text { Energy Systems }\end{array}$} & $\begin{array}{l}\text { Learner knows about different energy } \\
\text { resources- renewable and non-renewable- } \\
\text { their respective advantages and } \\
\text { disadvantages. }\end{array}$ & $\begin{array}{l}\text { Learner is able to develop a } \\
\text { vision of a sustainable energy } \\
\text { production, supply and usage } \\
\text { adapted to context. }\end{array}$ & $\begin{array}{l}\text { Learner is able to apply } \\
\text { measures in order to } \\
\text { increase energy efficiency } \\
\text { and sufficiency in their } \\
\text { personal sphere. }\end{array}$ \\
\hline & $\begin{array}{l}\text { Learner understands the concept of energy } \\
\text { efficiency and sufficiency and knows } \\
\text { strategies and policies to achieve them. }\end{array}$ & $\begin{array}{l}\text { Learner advocates for } \\
\text { affordable, reliable, sustainable } \\
\text { and clean energy adapted to } \\
\text { bio-cultural uniqueness of } \\
\text { landscapes. }\end{array}$ & $\begin{array}{l}\text { Learner is able to plan } \\
\text { measures to increase the } \\
\text { share of renewable energy } \\
\text { in their local energy mix. }\end{array}$ \\
\hline & $\begin{array}{l}\text { Learner compares and assesses different } \\
\text { business models and their suitability for } \\
\text { different energy solutions. }\end{array}$ & $\begin{array}{l}\text { Learner is able to communicate } \\
\text { the need for energy efficiency } \\
\text { and sufficiency. }\end{array}$ & $\begin{array}{l}\text { Learner is able to analyse } \\
\text { the impact and long-term } \\
\text { effects of a large energy } \\
\text { projects and energy related } \\
\text { policies on different } \\
\text { stakeholder groups. }\end{array}$ \\
\hline & $\begin{array}{l}\text { Learner understands how policies can } \\
\text { influence the development of renewable } \\
\text { energy production, supply and usage. }\end{array}$ & $\begin{array}{l}\text { Learner is able to engage others } \\
\text { in developing a business case } \\
\text { for a community-led } \\
\text { decentralised renewable energy } \\
\text { system. }\end{array}$ & $\begin{array}{l}\text { Learner is able to } \\
\text { influence public policies } \\
\text { related to renewable } \\
\text { energy production, supply } \\
\text { and usage. }\end{array}$ \\
\hline \multirow[t]{4}{*}{$\begin{array}{l}\text { Module } 5 \\
\text { Green Building and } \\
\text { Retrofitting }\end{array}$} & $\begin{array}{l}\text { Learner knows how to select building } \\
\text { materials and architectural styles best suited } \\
\text { to a specific cultural landscape. }\end{array}$ & $\begin{array}{l}\text { Learner advocates for } \\
\text { ecologically designed buildings } \\
\text { that function like an ecosystem } \\
\text { regenerating health and } \\
\text { wellbeing of their residents and } \\
\text { the ecosystems within which } \\
\text { they are located. }\end{array}$ & $\begin{array}{l}\text { Learner adopts } \\
\text { architectural style fitting } \\
\text { into the local vernacular. }\end{array}$ \\
\hline & $\begin{array}{l}\text { Learner knows the importance of minimising } \\
\text { construction /restoration waste by utilising } \\
\text { local available materials. }\end{array}$ & $\begin{array}{l}\text { Learner strengthens the ability } \\
\text { of communities and their } \\
\text { properties to eliminate the } \\
\text { concept of waste. }\end{array}$ & $\begin{array}{l}\text { Learner uses materials } \\
\text { sparingly to avoid } \\
\text { construction waste. }\end{array}$ \\
\hline & $\begin{array}{l}\text { Learner understands the need of optimising } \\
\text { full life cycle of products and processes and } \\
\text { implementing waste recycle measures. }\end{array}$ & $\begin{array}{l}\text { Learner promotes local } \\
\text { craftmanship in the construction } \\
\text { and restoration of buildings. }\end{array}$ & $\begin{array}{l}\text { Learner uses local } \\
\text { materials where possible } \\
\text { with low embedded } \\
\text { energy. }\end{array}$ \\
\hline & $\begin{array}{l}\text { Learner identifies role of different heating } \\
\text { and cooling technologies, bioclimatic } \\
\text { building, airtightness and ventilation, green } \\
\text { roofs, green walls. }\end{array}$ & $\begin{array}{l}\text { Learner promotes smart } \\
\text { buildings and smart grids. }\end{array}$ & $\begin{array}{l}\text { Learner ensures adequate } \\
\text { natural ventilation and } \\
\text { solar gain in construction. }\end{array}$ \\
\hline
\end{tabular}

\section{THE ECONOMIC DIMENSION}

Progress, development, expansion, prosperity, growth these words are intrinsically embedded in humanity's aspiration to constantly improve the quality of its existence (East, 2014). In the pursuit of constant growth, humanity today taps into natural resources at a level never before seen, participating in the planetary-wide decline of biodiversity, climate change, as well as a degenerative relationship to the natural world (Washington, 2018). The economic dimension explores the replacement of the linear economic model based on extracting-producing-using-discarding materials and energies with one that eliminates the concept of waste, uses energy and materials with great efficiency, and distributes wealth fairly within and between generations. Cultural landscapes are characteristically areas where people earn their livelihoods (UNESCO, 2017). The economic pathway explores how to engage with the redesign of local and regional economy embedded in cultural landscapes. It investigates where to start the process of becoming a social entrepreneur, establishing a cooperative or a community-led project that makes use of local resources and skills, preserve local knowledge systems and infrastructures, and make local communities and individuals, including marginalised populations, the primary stakeholders. 
Table 3. The economic dimension

\begin{tabular}{|c|c|c|c|}
\hline Modules & Cognitive Learning Outcomes & $\begin{array}{c}\text { Social-emotional Learning } \\
\text { Outcomes }\end{array}$ & $\begin{array}{c}\text { Behavioural Learning } \\
\text { Outcomes }\end{array}$ \\
\hline \multirow{4}{*}{$\begin{array}{l}\text { Module } 1 \\
\text { Shifting the Global } \\
\text { Economy Towards } \\
\text { Sustainability }\end{array}$} & $\begin{array}{l}\text { Learner describes the best places to } \\
\text { intervene in the system in order to shift } \\
\text { the global economy towards } \\
\text { sustainability. }\end{array}$ & $\begin{array}{l}\text { Learner is able to critically discuss } \\
\text { economic growth models and future } \\
\text { visions of economy and to } \\
\text { communicate them in public } \\
\text { spheres. }\end{array}$ & $\begin{array}{l}\text { Learner is able to bring } \\
\text { economic life into alignment } \\
\text { with ecological values. }\end{array}$ \\
\hline & $\begin{array}{l}\text { Learner understands the relationship } \\
\text { between 'externalities' and hidden } \\
\text { subsidies and trespassing planetary } \\
\text { boundaries. }\end{array}$ & $\begin{array}{l}\text { Learner is able to propose solutions } \\
\text { on how the global economy could } \\
\text { be more just, resilient and } \\
\text { sustainable. }\end{array}$ & Learner utilises ethical banks. \\
\hline & $\begin{array}{l}\text { Learner understands the concept of } \\
\text { solidarity economy in the context of } \\
\text { thriving and resilient communities. }\end{array}$ & $\begin{array}{l}\text { Learner is able to encourage } \\
\text { discussions on diverse community } \\
\text { currency schemes. }\end{array}$ & $\begin{array}{l}\text { Learner engages in social } \\
\text { enterprises. }\end{array}$ \\
\hline & $\begin{array}{l}\text { Learner identifies the most appropriate } \\
\text { legal forms and financing mechanisms } \\
\text { for regenerative economies. }\end{array}$ & $\begin{array}{l}\text { Learner advocates for innovative } \\
\text { income-generating enterprises in } \\
\text { and around cultural landscapes } \\
\text { rooted in tradition. }\end{array}$ & $\begin{array}{l}\text { Learner employs micro-credit } \\
\text { and other flexible finance to } \\
\text { support local enterprise. }\end{array}$ \\
\hline \multirow{4}{*}{$\begin{array}{l}\text { Module } 2 \\
\text { Responsible } \\
\text { Production and } \\
\text { Consumption }\end{array}$} & $\begin{array}{l}\text { Learner understands the impact that } \\
\text { production and consumption patterns } \\
\text { have on environment. }\end{array}$ & $\begin{array}{l}\text { Learner encourages others to } \\
\text { engage in sustainable practices in } \\
\text { consumption and production. }\end{array}$ & $\begin{array}{l}\text { Learner is able to make } \\
\text { consumption choices which } \\
\text { decouple production from } \\
\text { environmental degradation. }\end{array}$ \\
\hline & $\begin{array}{l}\text { Learner discusses the role of resource } \\
\text { efficiency and zero waste towards a } \\
\text { circular economy production. }\end{array}$ & $\begin{array}{l}\text { Learner is able to reflect their own } \\
\text { individual consumer behaviour and } \\
\text { related needs in light of natural } \\
\text { world, future generations, other } \\
\text { people, cultures and countries. }\end{array}$ & Learner reduces waste. \\
\hline & $\begin{array}{l}\text { Learner knows opportunities for as well } \\
\text { as strategies and practices of } \\
\text { sustainable production and } \\
\text { consumption. }\end{array}$ & $\begin{array}{l}\text { Learner encourages the use of low- } \\
\text { transformed materials. }\end{array}$ & $\begin{array}{l}\text { Learner is able to influence } \\
\text { decision-making processes } \\
\text { about local acquisitions in the } \\
\text { public sector. }\end{array}$ \\
\hline & $\begin{array}{l}\text { Learner is able to articulate the } \\
\text { importance of reinforcing bioregional } \\
\text { food systems and reducing carbon- } \\
\text { intensive transportation efforts. }\end{array}$ & $\begin{array}{l}\text { Learner promotes farm-to-table } \\
\text { schemes. }\end{array}$ & $\begin{array}{l}\text { Learner is able to speak against } \\
\text { unsustainable production } \\
\text { patterns. }\end{array}$ \\
\hline \multirow[t]{4}{*}{$\begin{array}{l}\text { Module } 3 \\
\text { Eco-tourism \& } \\
\text { eco-museums }\end{array}$} & $\begin{array}{l}\text { Learner discusses the role of eco- } \\
\text { tourism and eco-museums in } \\
\text { strengthening local culture and raising } \\
\text { environmental awareness of visitors. }\end{array}$ & $\begin{array}{l}\text { Learner encourages locally driven } \\
\text { responsible eco-tourism } \\
\text { management in and around cultural } \\
\text { landscapes for economic } \\
\text { diversification. }\end{array}$ & $\begin{array}{l}\text { Learner trains to become an } \\
\text { eco-tourism guide. }\end{array}$ \\
\hline & $\begin{array}{l}\text { Learner becomes aware of the strain } \\
\text { cheap travel puts on local ecologies and } \\
\text { individual geographical features. }\end{array}$ & $\begin{array}{l}\text { Learner promotes indigenous } \\
\text { workmanship and handicraft } \\
\text { products made with local materials. }\end{array}$ & $\begin{array}{l}\text { Learner values and develops } \\
\text { local workmanship skills. }\end{array}$ \\
\hline & $\begin{array}{l}\text { Learner knows how to choose between } \\
\text { different types and sources of finances, } \\
\text { and what legal structures might best } \\
\text { serve eco-tourism and eco-museums } \\
\text { embedded in and around cultural } \\
\text { landscapes. }\end{array}$ & $\begin{array}{l}\text { Learner advocates for low or } \\
\text { carbon neutral operations of trips } \\
\text { and excursions and hospitality } \\
\text { services. }\end{array}$ & $\begin{array}{l}\text { Learner develops historic and } \\
\text { eco-literacy. }\end{array}$ \\
\hline & $\begin{array}{l}\text { Learner knows the direct financial } \\
\text { benefit of eco-tourism for conservation } \\
\text { and empowerment of local people. }\end{array}$ & $\begin{array}{l}\text { Learner engages in the collective } \\
\text { curation of an eco-museum as a } \\
\text { tool for strengthening community } \\
\text { cohesion and identity of place. }\end{array}$ & $\begin{array}{l}\text { Learner joins a community- } \\
\text { based eco-tourism initiative } \\
\text { accompanied by inclusive and } \\
\text { equitable economic investment } \\
\text { ensuring benefit sharing. }\end{array}$ \\
\hline \multirow[t]{2}{*}{$\begin{array}{l}\text { Module } 4 \\
\text { Right Livelihood }\end{array}$} & $\begin{array}{l}\text { Learner knows about the concept of } \\
\text { right livelihood- earning a living in a } \\
\text { profession that brings no harm to others } \\
\text { or the natural world. }\end{array}$ & $\begin{array}{l}\text { Learner engages with local } \\
\text { community to develop economic } \\
\text { activities that contribute to well- } \\
\text { being of communities and } \\
\text { conservation of the landscape. }\end{array}$ & $\begin{array}{l}\text { Learner has a productive and } \\
\text { decent employment. }\end{array}$ \\
\hline & $\begin{array}{l}\text { Learner understands how cultural } \\
\text { landscape sites can enhance livelihoods } \\
\text { of communities and alleviate poverty of } \\
\text { marginalised populations. }\end{array}$ & $\begin{array}{l}\text { Learner advocates for right } \\
\text { livelihood as the foundation for } \\
\text { intelligent social activism and } \\
\text { ecological responsibility. }\end{array}$ & $\begin{array}{l}\text { Learner contributes to economic } \\
\text { activities that provide } \\
\text { employment for marginalised } \\
\text { populations. }\end{array}$ \\
\hline
\end{tabular}


Table 3. cont

\begin{tabular}{|c|c|c|c|}
\hline Modules & Cognitive Learning Outcomes & $\begin{array}{c}\text { Social-emotional Learning } \\
\text { Outcomes }\end{array}$ & $\begin{array}{c}\text { Behavioural Learning } \\
\text { Outcomes }\end{array}$ \\
\hline \multirow[t]{2}{*}{$\begin{array}{l}\text { Module } 4 \\
\text { Right } \\
\text { Livelihood }\end{array}$} & $\begin{array}{l}\text { Learner recognises the role of ethical } \\
\text { investment, microcredit, microfinance, } \\
\text { community currencies and crowdfunding } \\
\text { in creating a locally and regionally based } \\
\text { economy. }\end{array}$ & $\begin{array}{l}\text { Learner stimulates debates on } \\
\text { community currency systems. }\end{array}$ & $\begin{array}{l}\text { Learner joins a community } \\
\text { currency scheme. }\end{array}$ \\
\hline & $\begin{array}{l}\text { Learner knows the importance of } \\
\text { capacity-development programmes that } \\
\text { support traditional agricultural and craft } \\
\text { activities preserving skills and expertise. }\end{array}$ & $\begin{array}{l}\text { Learner advocates for the generation of } \\
\text { decent income and sustainable } \\
\text { livelihoods for local communities, } \\
\text { including marginalised populations. }\end{array}$ & $\begin{array}{l}\text { Learners engages in the political } \\
\text { processes for appropriate } \\
\text { environmental regulations of } \\
\text { businesses. }\end{array}$ \\
\hline \multirow[t]{4}{*}{$\begin{array}{l}\text { Module 5 } \\
\text { Revitalising } \\
\text { Local } \\
\text { Economies }\end{array}$} & $\begin{array}{l}\text { Learner understands how local economies } \\
\text { can strengthen community cohesion and } \\
\text { lead to greater human health and material } \\
\text { wellbeing, while reducing pollution and } \\
\text { degeneration of natural systems. }\end{array}$ & $\begin{array}{l}\text { Learner advocates for inclusive and } \\
\text { equitable economic investments in and } \\
\text { around cultural landscapes that make } \\
\text { use of local resources and skills. }\end{array}$ & $\begin{array}{l}\text { Learner joins local economy } \\
\text { networks of place-based } \\
\text { relationships- community } \\
\text { gardens to credit unions, co-ops. }\end{array}$ \\
\hline & $\begin{array}{l}\text { Learner understands the importance of } \\
\text { social investment that engages local } \\
\text { resources and skills. }\end{array}$ & $\begin{array}{l}\text { Learner supports economic activities } \\
\text { that preserve local knowledge systems } \\
\text { and infrastructures, and make local } \\
\text { communities, including marginalised } \\
\text { populations, the primary stakeholders. }\end{array}$ & $\begin{array}{l}\text { Learner employs micro-credit } \\
\text { and other flexible finance to } \\
\text { support local enterprise }\end{array}$ \\
\hline & $\begin{array}{l}\text { Learner knows the role of social } \\
\text { innovation and social entrepreneurship in } \\
\text { the revitalisation of local economies. }\end{array}$ & $\begin{array}{l}\text { Learner encourages local production } \\
\text { and trades. }\end{array}$ & $\begin{array}{l}\text { Learner respect local cultures } \\
\text { and needs, while allowing for } \\
\text { the free exchange of knowledge } \\
\text { and ideas across borders. }\end{array}$ \\
\hline & $\begin{array}{l}\text { Learners discusses opportunities and } \\
\text { challenges that can be drawn from eco- } \\
\text { social enterprises replacing dependence } \\
\text { on distant, unaccountable corporations. }\end{array}$ & $\begin{array}{l}\text { Learner advocates for an economy that } \\
\text { is created by and for the people who } \\
\text { live in and around the cultural } \\
\text { landscape. }\end{array}$ & $\begin{array}{l}\text { Learner joins campaign for local } \\
\text { government to shift taxes and } \\
\text { subsidies to support local, } \\
\text { sustainable businesses instead } \\
\text { of global corporations. }\end{array}$ \\
\hline
\end{tabular}

\section{THE CULTURAL DIMENSION}

There is a multitude of definitions of culture. Depending on the lens through which you are looking, culture can broadly describe the activities of artistic and intellectual life. It can also refer to a social language informing particular ways of life or group identity. There is also the perspective of culture as tradition and common cultural heritage. Chilean Biologist Maturana said 'all movement occurs while it is being inhibited, the dance of change is the inevitable interplay between forces producing innovation and growth and forces conserving stability (1998). This is the crucible of cultural activity in the $21^{\text {st }}$ century. Culture today is marked by a strong and creative tension between what is global and what is local. This dimension reinforces the uniqueness of place rooted in traditions conserving stability as well as welcoming innovation towards regenerative futures. Those who engage in the cultural design pathway might gain the knowledge, competencies and skills to become interdependent cultural creatives and thinkers. This dimension creates space for reflection on beliefs, values and ways of thinking by those engaged in the re-design of the human presence on cultural landscapes. It nourishes the dialogue between art and the state of the world, cultural landscape and deep ecology, personal health, and planetary health. 


\begin{tabular}{|c|c|c|c|}
\hline Modules & Cognitive Learning Outcomes & $\begin{array}{c}\text { Social-emotional Learning } \\
\text { Outcomes } \\
\end{array}$ & $\begin{array}{c}\text { Behavioural Learning } \\
\text { Outcomes }\end{array}$ \\
\hline \multirow{4}{*}{$\begin{array}{l}\text { Module } 1 \\
\text { Cultural } \\
\text { Landscape and } \\
\text { Deep Ecology }\end{array}$} & $\begin{array}{l}\text { Learner traces the roots of deep } \\
\text { ecology and knows how to compare/ } \\
\text { contrast shallow vs deep ecology. }\end{array}$ & $\begin{array}{l}\text { Learner is able to raise awareness on } \\
\text { the inherent worth of all life forms, } \\
\text { independent of the usefulness of the } \\
\text { nonhuman world for human purposes. }\end{array}$ & $\begin{array}{l}\text { Learner is able to nourish a deep } \\
\text { connection with Nature through } \\
\text { personal experience. }\end{array}$ \\
\hline & $\begin{array}{l}\text { Learner questions the fundamental } \\
\text { values that the linear industrial } \\
\text { paradigm is built upon. }\end{array}$ & $\begin{array}{l}\text { Learner is able to show sensitivity to } \\
\text { the issues of cultural landscape } \\
\text { regeneration. }\end{array}$ & $\begin{array}{l}\text { Learner is able to plan, implement } \\
\text { and evaluate projects embedded } \\
\text { in deep ecology principles. }\end{array}$ \\
\hline & $\begin{array}{l}\text { Learner knows facts and figures how } \\
\text { economic interests and excessive } \\
\text { human interference in landscapes is } \\
\text { accelerating degeneration. }\end{array}$ & $\begin{array}{l}\text { Learner is able to communicate issues } \\
\text { of Nature Rights. }\end{array}$ & $\begin{array}{l}\text { Learner is able to publicly } \\
\text { demand that local and national } \\
\text { laws taking in consideration } \\
\text { Nature Rights. }\end{array}$ \\
\hline & $\begin{array}{l}\text { Learner explains and gives example } \\
\text { on how Nature Rights have been } \\
\text { implemented in different countries. }\end{array}$ & $\begin{array}{l}\text { Learners is able to encourage others } \\
\text { to act in favour of Nature's Rights to } \\
\text { thrive. }\end{array}$ & $\begin{array}{l}\text { Learner is able to critically take } \\
\text { on their role as an active global } \\
\text { citizen seeking quality of living } \\
\text { instead of adhering to the infinite } \\
\text { growth paradigm. }\end{array}$ \\
\hline \multirow{4}{*}{$\begin{array}{l}\text { Module } 2 \\
\text { Traditional } \\
\text { Land-use and } \\
\text { Social Structure }\end{array}$} & $\begin{array}{l}\text { Learner understands the evolution of } \\
\text { the historic landscape concept and } \\
\text { how to interpret changes in traditional } \\
\text { land-use. }\end{array}$ & $\begin{array}{l}\text { Learner engages people for whom the } \\
\text { landscape has significant associations } \\
\text { and meanings. }\end{array}$ & $\begin{array}{l}\text { Learner is able to support others } \\
\text { in developing land-based rituals } \\
\text { and ceremonies which strengthen } \\
\text { social cohesion. }\end{array}$ \\
\hline & $\begin{array}{l}\text { Learner knows of the importance of } \\
\text { the underlying traditional social } \\
\text { structure engraved in the geological } \\
\text { history of the cultural landscape. }\end{array}$ & $\begin{array}{l}\text { Learner promotes traditional } \\
\text { knowledge and practices as a way to } \\
\text { strengthen social cohesion. }\end{array}$ & $\begin{array}{l}\text { Learner is able to use all } \\
\text { opportunities to preserve artistic } \\
\text { creations, built heritage, } \\
\text { geological and archaeological } \\
\text { heritage. }\end{array}$ \\
\hline & $\begin{array}{l}\text { Learner knows the difference between } \\
\text { tangible and intangible heritage. }\end{array}$ & $\begin{array}{l}\text { Learner is able to involve in local } \\
\text { community activities regarding oral } \\
\text { traditions, performing arts, local } \\
\text { knowledge, and traditional skills. }\end{array}$ & $\begin{array}{l}\text { Learner is able to influence } \\
\text { decision-making related to } \\
\text { preserving significant tangible } \\
\text { and intangible heritage. }\end{array}$ \\
\hline & $\begin{array}{l}\text { Learner understands the values } \\
\text { informing the imaginary experiences } \\
\text { of those who contribute to the cultural } \\
\text { landscape. }\end{array}$ & $\begin{array}{l}\text { Learner is able to cooperate and } \\
\text { collaborate with others to preserve } \\
\text { physical artefacts produced, } \\
\text { maintained and transmitted } \\
\text { intergenerationally in the cultural } \\
\text { landscape. }\end{array}$ & $\begin{array}{l}\text { Learner contributes to oral } \\
\text { traditions, performing arts, local } \\
\text { knowledge, and traditional skills. }\end{array}$ \\
\hline \multirow[t]{4}{*}{$\begin{array}{l}\text { Module } 3 \\
\text { Personal Health, } \\
\text { Planetary Health }\end{array}$} & $\begin{array}{l}\text { Learner understands the systemic } \\
\text { interdependencies between personal, } \\
\text { ecosystem and planetary health and } \\
\text { the major constraints to the patterns } \\
\text { that connect. }\end{array}$ & $\begin{array}{l}\text { Learner promotes biodiversity } \\
\text { campaigns that interlink community, } \\
\text { ecosystem and planetary health. }\end{array}$ & $\begin{array}{l}\text { Learner initiates activities that } \\
\text { nourish personal, ecosystem and } \\
\text { planetary health. }\end{array}$ \\
\hline & $\begin{array}{l}\text { Learner knows definitions and } \\
\text { conceptions of health and well-being } \\
\text { and can critically reflect on them. }\end{array}$ & $\begin{array}{l}\text { Learner is able to interact with people } \\
\text { suffering from illnesses on an equal } \\
\text { footing and feel empathy for their } \\
\text { situation and feelings. }\end{array}$ & $\begin{array}{l}\text { Learner develops health } \\
\text { promoting behaviours in their } \\
\text { daily life routines. }\end{array}$ \\
\hline & $\begin{array}{l}\text { Learner knows relevant prevention } \\
\text { strategies to foster positive physical } \\
\text { and mental health and well-being. }\end{array}$ & $\begin{array}{l}\text { Learner is able to encourage others to } \\
\text { decide and act in favour of promoting } \\
\text { health and well-being. }\end{array}$ & $\begin{array}{l}\text { Learner has the capacity to } \\
\text { perceive when others need help } \\
\text { and seek help for themselves and } \\
\text { others. }\end{array}$ \\
\hline & $\begin{array}{l}\text { Learner explains how healthy } \\
\text { lifestyles, greater equality, community } \\
\text { cohesion and a sense of belonging and } \\
\text { place contribute to a more holistic } \\
\text { understanding of health. }\end{array}$ & $\begin{array}{l}\text { Learner promotes healthy lifestyles as } \\
\text { a community practice. }\end{array}$ & $\begin{array}{l}\text { Learner is able to evaluate, } \\
\text { participate in and influence } \\
\text { decision-making related to health } \\
\text { and well-being of themselves and } \\
\text { others. }\end{array}$ \\
\hline \multirow[t]{2}{*}{$\begin{array}{l}\text { Module } 4 \\
\text { Gender and } \\
\text { Human Rights }\end{array}$} & $\begin{array}{l}\text { Learner understands levels of gender } \\
\text { equality within their context in } \\
\text { comparison to global norms, including } \\
\text { the intersectionality of gender within } \\
\text { other groups. }\end{array}$ & $\begin{array}{l}\text { Learner is able to recognise and } \\
\text { deconstruct traditional gender roles in } \\
\text { a culturally sensitive yet critical and } \\
\text { emancipatory approach. }\end{array}$ & $\begin{array}{l}\text { Learner supports human rights } \\
\text { and democratic movements. }\end{array}$ \\
\hline & $\begin{array}{l}\text { Learner knows the opportunities and } \\
\text { benefits provided by full gender } \\
\text { equality and participation in the } \\
\text { development of cultural landscapes. }\end{array}$ & $\begin{array}{l}\text { Learner is able to identify and speak } \\
\text { up against all forms of gender } \\
\text { discrimination and debate the benefits } \\
\text { of full empowerment of all genders. }\end{array}$ & $\begin{array}{l}\text { Learner is able to facilitate (where } \\
\text { possible) meetings to speak about } \\
\text { gender issues, such as } \\
\text { representation in decision making }\end{array}$ \\
\hline
\end{tabular}


Table 4. Cont.

\begin{tabular}{|c|c|c|c|}
\hline Modules & Cognitive Learning Outcomes & $\begin{array}{c}\text { Social-emotional Learning } \\
\text { Outcomes }\end{array}$ & $\begin{array}{c}\text { Behavioural Learning } \\
\text { Outcomes }\end{array}$ \\
\hline \multirow{2}{*}{$\begin{array}{l}\text { Module } 4 \\
\text { Gender and } \\
\text { Human Rights }\end{array}$} & $\begin{array}{l}\text { Learner understands the importance of } \\
\text { inclusion and representing those that } \\
\text { cannot speak for their own rights. }\end{array}$ & $\begin{array}{l}\text { Learner can debate local and global } \\
\text { justice issues. }\end{array}$ & $\begin{array}{l}\text { Learner can critically assess } \\
\text { issues of justice in their region. }\end{array}$ \\
\hline & $\begin{array}{l}\text { Learner understands gender as } \\
\text { representation of sexual difference, } \\
\text { and that the concept is a malleable } \\
\text { cultural construction. }\end{array}$ & $\begin{array}{l}\text { Learner is able to connect with others } \\
\text { who work to end gender } \\
\text { discrimination empower those who } \\
\text { may still be disempowered and } \\
\text { promote full equality at all levels. }\end{array}$ & $\begin{array}{l}\text { Learner can become an agent of } \\
\text { change in local decision-making, } \\
\text { speaking up against injustice. }\end{array}$ \\
\hline \multirow{4}{*}{$\begin{array}{l}\text { Module } 5 \\
\text { Cultural and } \\
\text { Natural } \\
\text { Regeneration }\end{array}$} & $\begin{array}{l}\text { Learner knows the importance of } \\
\text { identification and retaining the bio } \\
\text { cultural uniqueness of place. }\end{array}$ & $\begin{array}{l}\text { Learner engages stakeholders to } \\
\text { foster understanding on regenerative } \\
\text { approaches to cultural landscape } \\
\text { vitality over time. }\end{array}$ & $\begin{array}{l}\text { Learner is able to identify value- } \\
\text { added activities while retaining } \\
\text { the essence of the landscape. }\end{array}$ \\
\hline & $\begin{array}{l}\text { Learner understands the need to shift } \\
\text { from dominance to intimacy with } \\
\text { nature through mutually beneficial } \\
\text { interaction. }\end{array}$ & $\begin{array}{l}\text { Learner promotes regenerative } \\
\text { potential nested in living systems- } \\
\text { social and biotic }\end{array}$ & $\begin{array}{l}\text { Learner facilitates collective } \\
\text { imaging processes that make the } \\
\text { significance of the cultural } \\
\text { landscape more vivid and } \\
\text { energising. }\end{array}$ \\
\hline & $\begin{array}{l}\text { Learner understands the concepts of } \\
\text { vitality and viability within living } \\
\text { systems. }\end{array}$ & $\begin{array}{l}\text { Learner is able to advocate for } \\
\text { regenerative development aligned to } \\
\text { the vocation of place and cultural } \\
\text { significance. }\end{array}$ & $\begin{array}{l}\text { Learner is able to cooperate with } \\
\text { local authorities in the } \\
\text { development of regenerative } \\
\text { strategies }\end{array}$ \\
\hline & $\begin{array}{l}\text { Learner integrates consideration for } \\
\text { biological and cultural diversity as } \\
\text { well as ecosystem services and } \\
\text { benefits within the management } \\
\text { cultural landscapes. }\end{array}$ & $\begin{array}{l}\text { Learner is able to harness potential of } \\
\text { the cultural landscape as a source of } \\
\text { collective motivation. }\end{array}$ & $\begin{array}{l}\text { Learner becomes a regenerative } \\
\text { designer and developer. }\end{array}$ \\
\hline
\end{tabular}

\section{CONCLUSIONS}

This paper proposes a guidance framework of learning objectives for those seeking to build cognitive, socioemotional and personal competencies in the process of identifying, protecting, conserving, presenting and transmitting cultural landscapes for present and future generations. It does so under regenerative conceptual premisses which argue that even in an unpredictable world, we can enable the places where we live and work to thrive, going well beyond merely sustaining a precarious balance (Regenesis Group, 2017).

By harnessing four educational strands this paper has developed a comprehensive framework for engaging with sustainable cultural landscapes. The learning framework is rooted in the ecovillage model and the education it provides.

The quintessence of the ecovillage proposition is presented as a viable way to eradicate inequality and the degradation of the environment, while also creating a supportive social-cultural environment with a low-impact lifestyle.

The paper draws inspiration from international debates on the role of ESD in the acceleration of the implementation of the Sustainable Development Goals. It also reflects on outcomes of EU-funded projects such as VerSus (2014) and SUMCULA (2020). Finally, it incorporates design principles springing from a generation of sustainability designers co-evolving self-regulating natural systems (Regenesis, 2017; Wann, 1996; Wahl, 2016; Orr, 2002).
In order to create a whole-systems guidance framework that integrates complex systems as a cultural landscape does, a wide variety of viewpoints were included into the decisionmaking process. This integration had to span beyond transdisciplinarity among academic disciplines to include community and traditional ways of knowing and other participatory epistemologies (Vester, 2004). Further research may consider exploring the topic of learning environments and associated pedagogical approaches to deliver meaningful learning experiences. Other areas of research may consider the use of IT and communication technology to document, understand and present the complex layering of cultural landscape from an ESD perspective.

Cultural landscapes can be seen as territories where humans within Earth systems evolve in co-mutualism. Developing an understanding of historical geology alongside traditional settlement patterns, as well as taking into account tangible, intangible and spiritual values that have unfolded through generations, can act as a bridge between past, present and future, between story of place and place-sourced potential. This paper contributes to the international debate on how to accelerate the efforts to protect ecosystems while promoting socio-economic regeneration, both guided by the recognition of our growing interdependence and a common analysis of the opportunities, risks and challenges of the future. 


\section{REFERENCES}

Breuer, A., Janetschek, H. and Malerba, D. (2019): Translating Sustainable Development Goal (SDG) Interdependencies into Policy Advice. Sustainability. 11, 2092. DOI: $10.3390 /$ su11072092

Buckler, C. and Creech, H. (2014): Shaping the Future We Want. DESD Monitoring and Evaluation UN Decade of Education for Sustainable Development (2005-2014). Final Report. UNESCO. ISBN 978-92-3-100053-9

Brundtland, G., (1987): Report of the World Commission on Environment and Development: Our Common Future. United Nations General Assembly Document A/42/427.

Correia, M., Dipasquale, L., Mecca, S. (Eds.) (2014): VERSUS: Heritage for Tomorrow. Vernacular Knowledge for Sustainable Architecture. Florence (Italy): FUP Firenze University Press: 280p.

Delors, J. (1996): Learning: The Treasure Within- Learning to know, to do, to be and to live together. The Delors Report to UNESCO of the International Commission on Education for the Twenty-first Century. Delors Commission.

East, M. (2008): Ecovillages, design at the edge. Kosmos Journal. Spring/Summer 2008. Kosmos Journal - Journal for Global Transformation

East, M. (2018): SDGs: framing a new regenerative narrative. World Goodwill Seminar. Palais de Nations. [online] Available:

https:/www.lucistrust.org/world_goodwill/homepage/world goodwill_homepage/newsletter_2019_1_resonance

[Accessed 3 November 2020].

Freire, P. (1970): Pedagogy of the Oppressed. Continuum International Publishing Group, Inc.; New York.

ISBN - 0-8264 -1276-9

Gaia Education, (2012): Ecovillage Design Education - A four-week comprehensive course in the fundamentals of Sustainability Design. Curriculum conceived and designed by the GEESE - Global Ecovillage Educators for a Sustainable Earth. Version 5.

Giangrande, N., White, R. M., East, M., Jackson, R., Clarke, Tim, Coste, M. S., Penha-Lopes, G. (2019): A Competency Framework to Assess and Activate Education for Sustainable Development: Addressing the UN Sustainable Development Goals 4.7 Challenge. Sustainability 2019, 11, 2832.

DOI: $\underline{10.3390 / \mathrm{su} 11102832}$

Imram, S., Khorshed, A. and Beaumont, N. (2014): Reinterpreting the Definition of Sustainable Development for a More Ecocentric Reorientation. Sustainable Development Sust. Dev. 22, 134-144. Wiley Online Library.

DOI: $\underline{10.1002 / \mathrm{sd} .537}$
Jacques, D. (1995): The Rise of Cultural Landscapes. International Journal of Heritage Studies, 1-2: 91- 101. DOI: $10.1080 / 13527259508722136$

Jung, C. J. (1971): Mandala Symbolism. Princeton University Press. ISBN 9780691654614

Kopnina, H., Taylor, B., Washington, H. and Piccolo, J. (2018): Anthropocentrism: More Than Just a Misunderstood Problem. Journal of Agricultural and Environmental Ethics 31 (1): 109-27.

DOI: $\underline{10.1007 / \mathrm{s} 10806-018-9711-1}$

Leicht, A., Heiss, J. and Byun,W.J. (2018): Issues and trends in Education for Sustainable Development. Education on the Move. Education 2030. UNESCO.

http://unesdoc.unesco.org/images/0026/002614/261445e.pdf

Lunn, J., Downing, E., and Booth, L. (2015): The Sustainable Development Goals and the post-2015 development agenda. House of Commons Briefing Paper. Number 7291.

Muir, J. (1911): My First Summer in the Sierra, Essays. Library of America. ISBN: 978-1-59853-111-4

Orr, D. W. (2002): The Nature of Design. Oxford University Press. ISBN-13: 978-0195173680; ISBN-10: 0195173686

Nilsson, M. and Stevance, A-S. (2016): Understanding how the SDGs interact with each other is key to their success. [online] Available at:

https://www.weforum.org/agenda/2016/07/understandinginteractions-is-key-to-making-the-sdgs-a-success/

[Accessed 12 November 2020].

Noguchi, F., Guevara, J.R. and Yorozu, R. (2015): Communities in Action: Lifelong Learning for Sustainable Development. Hamburg, Germany: UNESCO Institute for Lifelong Learning. ISBN-978-92-820-1197-3

Potthoff, K. (2013): The use of 'cultural landscape' in 19th century German geographical literature. Norsk Geografisk Tidsskrift. Norwegian Journal of Geography. Volume 67, Issue 1 pp. 49-54 67(1).

DOI: $\underline{10.1080 / 00291951.2012 .759617}$

Regenesis Group (2017): The Regenerative Practitioner. Systemic Frameworks. Regenesis Group, Inc.

https://regenesisgroup.com/resources/

Ritter, C. (1862): Geography in Relation to Nature and the History of Mankind. (In German: Die Erdkunde in Verhältniss zur Natur un zur Geschichte des Menschen) G. Reimer, Berlin, 1862.

Rössler, M. C. (2006): World Heritage cultural landscapes: A UNESCO flagship programme 1992-2006, Landscape Research. 31:4, 333-353.

DOI: $\underline{10.1080 / 01426390601004210}$ 
GAIA Education (2018): SUMCULA, Sustainable Management of Cultural Landscape, [online]. Available at:

https://www.gaiaeducation.org/face-to-

face/sustainable-management-of-cultural-landscapesumcula/ [Accessed 1 Dec 2020].

UNESCO (2005): United Nations Decade of Education for Sustainable Development (2005-2014): International Implementation Scheme. Section for Education for Sustainable Development (ED/PEQ/ESD) Division for the Promotion of Quality Education. UNESCO.

https://unesdoc.unesco.org/ark:/48223/pf0000141629

UNESCO (2017): UNESCO moving forward the 2030 Agenda for Sustainable Development. UNESCO Task Force on the 2030 Agenda for Sustainable Development

https://fr.unesco.org/creativity/sites/creativity/files/247785en . $\mathrm{pdf}$

UNESCO (2017): Education for Sustainable Development Goals Learning Objectives. Section of Education for Sustainable Development and Global Citizenship, Division for Inclusion, Peace and Sustainable Development, Education Sector, UNESCO.

https://unesdoc.unesco.org/ark:/48223/pf0000247444

UNESCO (1972): Convention Concerning the Protection of the World Cultural and Natural Heritage. Adopted by the General Conference at its seventeenth session Paris.

https://whc.unesco.org/archive/convention-en.pdf

UNESCO (2008): Operational Guidelines for the Implementation of the World Heritage Convention. World Heritage Committee. World Heritage Centre Web.

https://whc.unesco.org/en/guidelines/

UNESCO (2015): What is Education for Sustainable Development. [online]. Available at:

https://en.unesco.org/themes/education-sustainabledevelopment/what-is-esd/s [Accessed 25 Nov 2020].

UNESCO (2017): Education for Sustainable Development Goals report. https://www.sdg4education2030.org/educationsustainable-development-goals-learning-objectives-unesco$\underline{2017}$
UNESCO (2020): Education for Sustainable Development: a roadmap. Section of Education for Sustainable Development, Division for Peace and Sustainable Development, Education Sector, UNESCO.

https://unesdoc.unesco.org/ark:/48223/pf0000374802

United Nations (1992): Agenda 21, The Rio Declaration on Environment and Development. United Nations Conference on Environment \& Development. Rio de Janeiro.

https://sustainabledevelopment.un.org/outcomedocuments/a genda21

United Nations (2002): Johannesburg Declaration on Sustainable Development. World Summit on Sustainable Development. A/CONF.199/20. Johannesburg. https://digitallibrary.un.org/record/478154? ln=en

United Nations (2015): Transforming our World: the 2030 Agenda for Sustainable Development. Adopted by the General Assembly on 25 September 2015. Seventieth session. Agenda items 15 and 116. (Resolution A/RES/70/1, 2015).

UNSSC (2016): The 2030 Agenda for Sustainable Development. United Nations System Staff College Knowledge Centre for Sustainable Development. [online] Available at: https://www.unssc.org/sites/unssc.org/files/2030 agenda for sustainable development_kcsd primer_en.pdf [Accessed 2 December 2020].

Vare, P., Scott, W. (2007): Learning for a Change: Exploring the Relationship Between Education and Sustainable Development. Journal of Education for Sustainable Development 1(2): $191-198$.

DOI: $10.1177 / 097340820700100209$

Vester, F. (2004): Die Kunst vernetzt zu Denken - Ideen und Werkzeuge für einen neuen Umgang mit Komplexität. Der Neue Bericht an den Club of Rome, Deutscher Taschenbuch Verlag. ISBN-10: 3423330775; ISBN-13: 978-3423330770

Wahl, D. C. (2016): Designing Regenerative Cultures. Triarchy Press. ISBN: 978-1-909470-77-4

Wann, D. (1996): Deep Design: Pathways To A Livable Future. Island Press. ISBN-10: 1559634200; ISBN-13: 9781559634205

(C) 2021 by the author(s). This article is an open-access article distributed under the terms and conditions of the Creative Commons Attribution (CC BY) license (http://creativecommons.org/licenses/by/4.0/). 